\title{
Black Russian Terrier
}

National Cancer Institute

\section{Source}

National Cancer Institute. Black Russian Terrier. NCI Thesaurus. Code C54048.

The Black Russian Terrier is a rare Russian breed that is robust, strong, large, stable and alert. The head is powerfully built with a broad skull and a long head. A mustache and beard add to the squaring off of the muzzle. It has large and powerful jaws with a coarse, waterproof coat that covers the legs with 2 to 4 inches hair. The very large, bear-like feet are fully covered with hair and have tough, black, thick pads. Height: 25-29 inches (64-74 cm.) Weight: 80-143 pounds (36-65 kg.) 